\title{
Differential Expression of Preproenkephalin and Preprodynorphin mRNAs in Striatal Neurons: High Levels of Preproenkephalin Expression Depend on Cerebral Cortical Afferents
}

\author{
George R. Uhl, ${ }^{1}$ Bradford Navia, ${ }^{2}$ and James Douglas ${ }^{3}$ \\ ${ }^{1}$ Gene Neuroscience Unit, ARC, NIDA, Departments of Neurology and Neuroscience, Johns Hopkins University School of \\ Medicine, Baltimore, Maryland 21224, and Department of Neurology, Massachusetts General Hospital and Harvard \\ Medical School, Boston, Massachusetts 02114, 2 Program in Neuroscience, Harvard Medical School, Boston, \\ Massachusetts 02115, and ${ }^{3}$ nstitute for Advanced Biomedical Research, Oregon Health Sciences University, Portland, \\ Oregon 97201
}

\begin{abstract}
Preproenkephalin and preprodynorphin mRNAs can be detected by in situ hybridization in medium-sized striatal neurons in normal rats and in rats with unilateral cerebral cortical lesions. Hybridization of ${ }^{35} \mathrm{~S}$-labeled oligonucleotide cDNAs complementary to specific regions of each mRNA reveals that preproenkephalin-expressing neurons are more numerous than cells expressing preprodynorphin. Hybridization densities above enkephalin-positive neurons are also more than twice those noted above preprodynorphin-expressing cells. Northern analyses of mRNA extracted from the striatum are consistent with these relationships. The striatal preproenkephalin hybridization densities are decreased ipsilateral to cerebral cortical lesions; this change evolves largely between 1 and $5 \mathrm{~d}$ following the lesion. Striatal preproenkephalin mRNA is thus more prominent than preprodynorphin mRNA and depends on cerebral cortical inputs for its full expression.
\end{abstract}

The 2 opiate peptide genes that are prominently expressed in the brain, preprodynorphin (preproenkephalin B) and preproenkephalin (preproenkephalin A), are members of a gene family that encodes structurally related peptide products (Comb et al., 1982; Noda et al., 1982a, b; Horikawa et al., 1983; Howells et al., 1984; Rosen et al., 1984; Civelli et al., 1985). Several lines of evidence suggest that expression of the peptides derived from each of these genes can influence a specific constellation of brain functions. Each peptide preferentially impacts a different group of opiate receptor subtypes, and each is expressed in distinct groups of neurons with different connectivities (Elde et al., 1976; Hökfelt et al., 1977; Lord et al., 1977; Uhl et al., 1978a, b; Snyder and Childers, 1979; Goodman et al., 1980; Graybiel et al., 1981; Chavkin et al., 1982; DiFiglia et al., 1982; Goodman and Snyder, 1982; Robson et al., 1983; Williams and Dockray, 1983; Akil et al., 1984; Christensson-Nylander et al., 1986).

\footnotetext{
Received Feb. 26, 1988; revised Apr. 8, 1988; accepted Apr. 14, 1988.

We gratefully acknowledge discussions with Drs. M. DiFiglia, G. Heinrich, and A. Tobin; assistance from K. Hill, L. Lloyd, M. Chaar, J. Canniff, C. Sasek, C. Vo, and G. Gryan, and support from the Howard Hughes Medical Institute, McKnight Foundation, Sloan Foundation, American Parkinson Disease Association, and NINCDS.

Correspondence should be addressed to George R. Uhl, M.D., Ph.D., Gene Neuroscience Unit, ARC, NIDA, Box 5180, Baltimore, MD 21224.

Copyright $\odot 1988$ Society for Neuroscience $0270-6474 / 88 / 124755-10 \$ 02.00 / 0$
}

These factors underscore the importance of examining the relative levels of regulated expression of each of these genes in their appropriate neuronal populations.

Both preproenkephalin and preprodynorphin are expressed at high levels in the striatum, a brain region that powerfully modulates locomotor activity (Civelli et al., 1985; Pittius et al., 1985). The most prominent input to this region is from cerebral cortical cells that are thought to exert excitatory influences on striatal targets (Penney and Young, 1983). Immunohistochemistry demonstrates peptide translation products of both the preproenkephalin and preprodynorphin genes in striatal neurons (e.g., Vincent et al., 1982; Penny et al., 1986). Unfortunately, difficulties in quantitation and in eliminating any possibility of cross-reactivity limit the information from this approach. Thus, at a cellular level there has been difficulty in ascertaining which gene is expressed at a higher level and/or how striatal expression of these opioid peptides is regulated.

We now report development and validation of in situ hybridization methods for detection and relative quantitation of preproenkephalin and preprodynorphin mRNAs in brain tissue sections using oligonucleotide cDNA probes directed against several different regions of each mRNA. We describe the distribution and relative intensity of hybridization to neurons containing each mRNA in rat striatum. The preponderance of preproenkephalin mRNA noted in these in situ studies is confirmed by analyses of RNAs extracted from this region. We also demonstrate regulation of cellular expression of preproenkephalin mRNA in response to lesions removing cerebral cortical inputs to the striatum.

\section{Materials and Methods \\ In situ hybridization}

Tissue preparation. Brains from normal and unilaterally lesioned 250 gm male Sprague-Dawley rats were used for these studies. Unilateral cerebral cortical aspiration lesions or sham operations were performed under chloral hydrate anesthesia, and animals were allowed to recover for varying periods of time. At sacrifice, anesthetized rats were perfused and the brains postfixed with PLPG (0.5\% depolymerized paraformaldehyde $/ 1 \%$ glutaraldehyde $/ 75 \mathrm{~mm}$ L-lysinc $/ 37.5 \mathrm{~mm}$ sodium phosphate, pH 7.4/10 mm sodium periodate) (Uhl and Reppert, 1987). Brains were soaked for $30 \mathrm{~min}$ in $15 \%$ sucrose in phosphate buffer, rapidly frozen, and sectioned at 5 or $10 \mu \mathrm{m}$ with thaw-mounting onto slides pretreated by acetylation and coated with Denhardt's solution $(0.02 \%$ BSA $0.02 \%$ ficol $/ 0.02 \%$ polyvinylpirolidine), as described (Uhl and Reppert, 1987).

Sections were pretreated for $20 \mathrm{~min}$ at $22^{\circ} \mathrm{C}$ with $0.2 \mathrm{M} \mathrm{HCl}$, and 15 


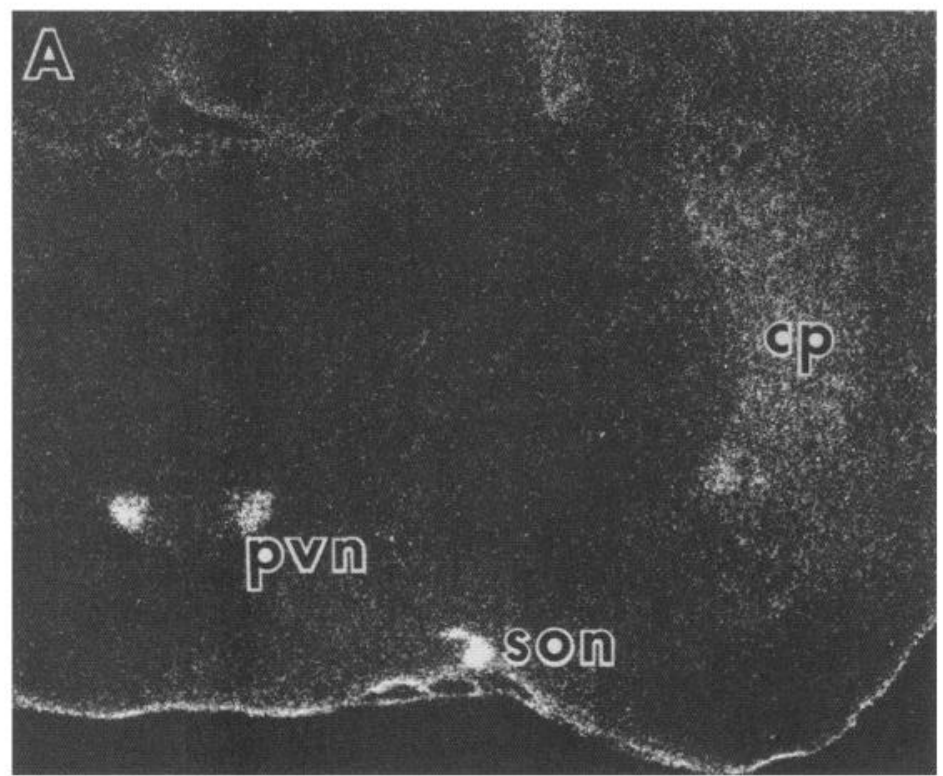

Figure 1. Hybridization densities for a preprodynorphin cDNA (RDYN $3^{\prime}$ ) $(A)$ and for an enkephalin cDNA (RENK $\left.3^{\prime}\right)$ at the level of the supraoptic (son) and paraventricular ( $p v n)$ nuclei of the hypothalamus and the striatum $(c p)$. Lighter areas correspond to increasing hybridization densities in these prints of film autoradiograms. These sections display the anatomic distribution of hybridization for each probe but were hybridized to differing probe concentrations and exposed for differing periods of time. Original magnification, $\times 13$.

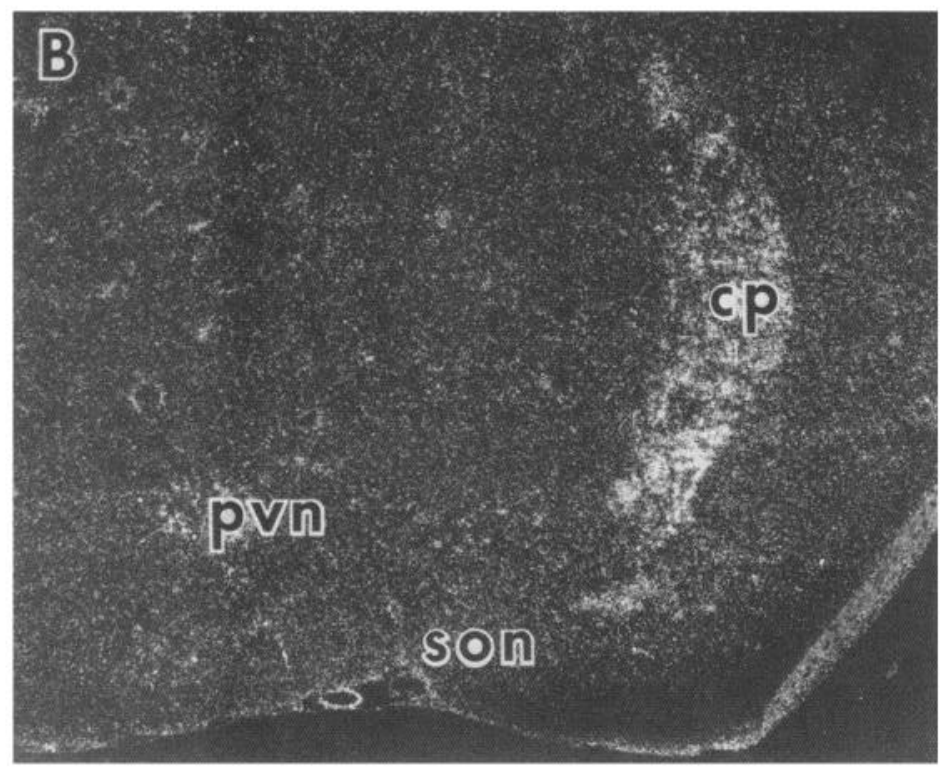

min at $37^{\circ} \mathrm{C}$ with proteinase $\mathrm{K}(1 \mu \mathrm{g} / \mathrm{ml}$ in $10 \mathrm{~mm}$ Tris $\mathrm{HCl}$, pH 7.4/2 mм calcium chloride) (Brahic and Haase, 1978; Uhl and Reppert, 1987). In some experiments, slides were incubated for $30 \mathrm{~min}$ in $25 \mu \mathrm{g} / \mathrm{m}$ ribonuclease A to establish a control (Gee et al., 1983). Slides were then dehydrated in ethanol and air-dried at room temperature.

${ }^{35} S$ - and ${ }^{32} P$-labeled cDNA oligonucleotide preparation. Forty-five base mRNA-sense template oligonucleotides corresponding to 2 regions of the rat preproenkephalin mRNA and 3 regions of the rat preprodynorphin mRNA were synthesized chemically using an Applied Biosystems oligonucleotide synthesizer. These regions were selected to provide probes that were specific for different regions of the preproenkephalin or preprodynorphin mRNAs but lacked extensive palindromic sequences. An- tisense 12 base cDNA "primers" complementary to regions beginning ca. 5 bases from the 3'-end of the "template" strand mRNA were synthesized. These complementary DNA sequences were allowed to hybridize to each other, and the antisense strand extended using Klenow fragment of DNA polymerase I, ${ }^{35}$ S-labeled dCTP and dATP (Amersham) and unlabeled dGTP and dTPP as described (Uhl et al., 1985). Radiolabeled product was separated from the template using $12 \%$ polyacrylamide gel electrophoresis under denaturing conditions and eluted using boiling water. Mean specific activities were $11,500 \mathrm{Ci} / \mathrm{mmol}$ for the enkephalin probes and 11,773 for the dynorphin probes. Mean lengths and guanine and cytosine contents were 38 ( $23 \mathrm{G} \mathrm{\&} \mathrm{C)}$ for the enkephalin probes and $41(20 \mathrm{G} \mathrm{\&} \mathrm{C)}$ for the dynorphin probes.

Figure 2. Prints of film autoradiograms demonstrating densities of hybridization of preproenkephalin and preprodynorphin cDNAs to sections of the striatum $(c p)$ and cerebral cortex $(c x)$ of a rat. Lighter areas correspond to denser hybridization in these images. Original magnification, $\times 13$. $A$, Hybridization of ${ }^{35}$ S-labeled preprodynorphin cDNA RDYN 7'. B, Hybridization of ${ }^{35}$ S-labeled RDYN $7^{\prime}$ to a section $30 \mu \mathrm{m}$ from $A$, treated identically except that $2 \mathrm{pmol} / \mu \mathrm{l}$ unlabeled RDYN 7 was added to establish a control. $C$. Hybridization of ${ }^{35}$ S-labeled RENK $3^{\prime}$ cDNA to a section adjacent to that hybridized in $A$. $D$, Hybridization of ${ }^{35}$ S-labeled RENK $3^{\prime}$ cDNA to a section $30 \mu \mathrm{m}$ from $C$, treated identically except that 2 $\mathrm{pmol} / \mu \mathrm{l}$ unlabeled RENK 3 was added to establish a control. $E$, Hybridization of ${ }^{35}$ S-labeled RENK $3^{\prime}$ to a section $20 \mu \mathrm{m}$ from $C$ that was pretreated with RNAse $A$ for 20 min prior to hybridization. 

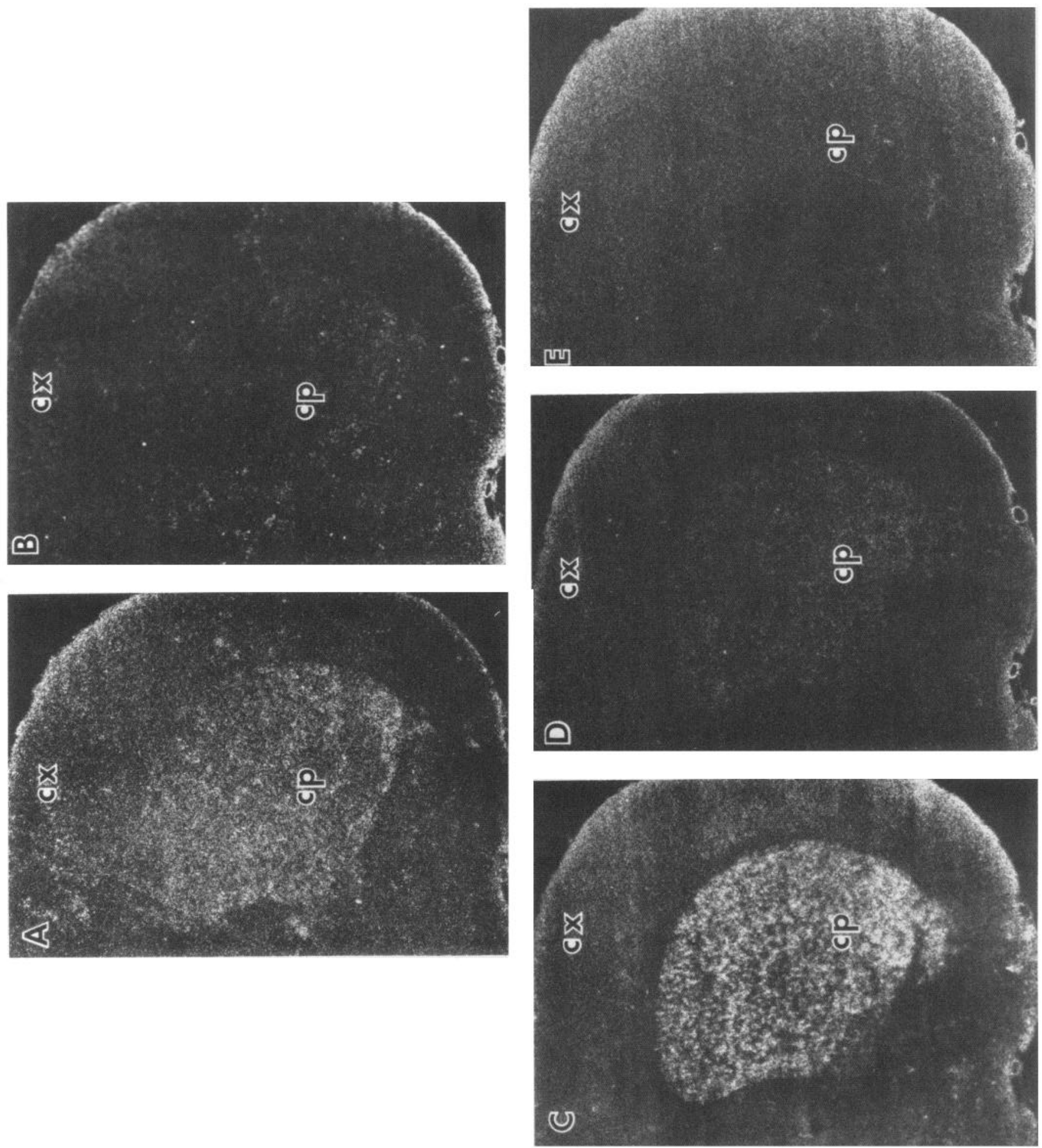

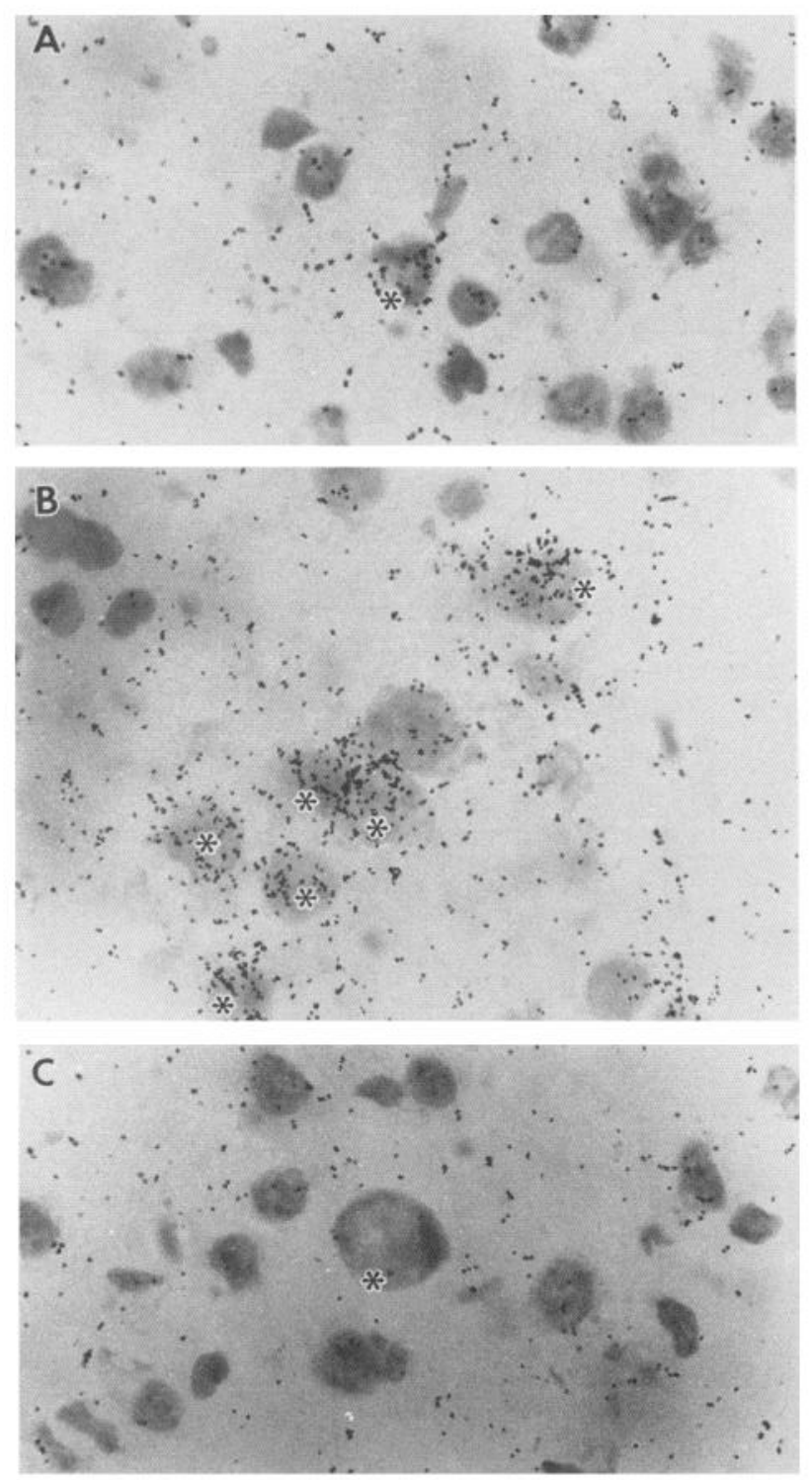

Figure 3. Photomicrographs of emulsion autoradiograms demonstrating preprodynorphin and preproenkephalin cDNA hybridization densities overlying individual neurons in the striatum. These images are derived from experiments performed in serial sections of the same brain hybridized with equivalent amounts of radiolabeled cDNA and exposed for the same time. $A$, Medium-sized striatal neuron labeled with ${ }^{35} \mathrm{~S}$ RDYN 7'; cDNA (asterisk). B, A cluster of medium-sized striatal neurons labeled with ${ }^{35}$ S-RENK 3 ' cDNA (asterisks). $C$, A large striatal neuron unlabeled by ${ }^{35}$ S-RDYN 7' (asterisk). Objective magnification, $100 \times$ for each.

For control experiments, an oligonucleotide complementary to a 35 base region of $\beta$ tubulin mRNA was $5^{\prime}$-end-labeled using $\gamma^{-{ }^{32}} \mathrm{P}$-ATP and gel-purified as described (Uhl, 1988).

Hybridization and washing. Either $1 \times 10^{4} \mathrm{cpm}$ [experiment I] or 2 $\times 10^{3} \mathrm{cpm} / \mu \mathrm{l}$ [experiments II-V] of ${ }^{35} \mathrm{~S}$-labeled antipreproenkephalin or antipreprodynorphin cDNA was applied to each tissue section in a complex hybridization buffer with $0.8 \mathrm{M} \mathrm{NaCl}$ and $60 \%$ (vol/vol) deionized formamide (Uhl et al., 1985). In some experiments, $1 \mu \mathrm{M}$ unlabeled sequence of the same or opposite sense to the radiolabeled hybridization probe was added to the hybridization mixtures to establish a control (Uhl, 1986). The hybridization and washing were performed as described except that in some experiments washing temperatures were varied between 45 and $70^{\circ} \mathrm{C}$ (Gee et al., 1983). Autoradiograms were generated by apposition of LKB Ultrofilm and by dipping slides in emulsion (Kodak NTB2, diluted 1:1 with water).
Analysis. Optical densities over the striatum were determined in LKB Ultrofilm autoradiographic images by means of the RAAS-1000 system (Amersham/Loats Associates, Westminster, MD). Anatomical boundaries were confirmed by analysis of toluidine blue-stained adjacent sections. A linear relationship between film optical density and radioactivity was confirmed using ${ }^{35} \mathrm{~S}$-brain paste standards of known activity (Uhl et al., 1986). Standards were also constructed by adsorbing known amounts of enkephalin mRNA-sense sp6 product (see below) onto 1 $\mathrm{cm}^{2}$ nylon filters, baking the filters for $2 \mathrm{hr}$ at $80^{\circ} \mathrm{C}$, and subjecting these filters to the hybridization and wash conditions used for the tissue sections (Uhl, 1988).

Microscopic analysis of emulsion autoradiographic images generated in this study focused on sections through the anterior striatum (for unlesioned rats) or the midstriatum at the level of the globus pallidus (for lesioned animals). We identified neurons in the toluidine bluestained sections underlying the in situ hybridization emulsion autoradiograms based on cell size, shape, nuclear characteristics, and presence of nucleoli. Only neurons whose representation in the toluidine bluestained sections included their nuclei were included, in order to avoid substantial partial voluming effects (Uhl and Sasek, 1986). After determination of an appropriate cell, the plane of focus was moved from the level of the tissue to the level of the emulsion, and autoradiographic grains lying in a $10 \times 10 \mu \mathrm{m}$ zone overlying the neuron were counted manually. This process was repeated for every neuron lying within a $100 \times 100 \mu \mathrm{m}$ grid. The microscopic stage was then moved so that an adjacent $100 \times 100 \mu \mathrm{m}$ area was analyzed. Sampling of the striata from normal brains began in the anterior dorsal striatum underlying the corpus callosum and continued ventrally. Values from 100 neurons were sampled from each section. Serial sections were hybridized with alternating preproenkephalin and preprodynorphin probes. For lesioned animals, values for 30 neurons lying in the $1 / 3$ of the striatum midway between its dorsal and ventral boundaries were sampled on each side. Background grain densities were obtained for each section from ten 10 $\times 10 \mu \mathrm{m}$ areas of emulsion away from labeled neurons. These values (ca. 2-3 grains $/ 10 \mu \mathrm{m}^{2}$ in normal tissues) were subtracted from observed values overlying cells before further analysis to provide a correction for autoradiographic background.

\section{Northern analyses}

$R N A$ extraction from regional brain samples. Total RNA was extracted from brain tissue by sonication in $10 \mathrm{vol}$ of $4 \mathrm{M}$ guanidinium thiocyanate $/ 0.5 \%$ sodium $N$-laurylsarcosine $/ 25 \mathrm{~mm}$ sodium citrate $/ 0.1 \mathrm{M}$ 2-mercaptoethanol, and the samples were centrifuged through $4 \mathrm{ml}$ of a $5.7 \mathrm{M} \mathrm{CsCl} / 25 \mathrm{~mm}$ sodium acetate solution (pH 5.0) for $20 \mathrm{hr}$ at $32,000 \mathrm{rpm}(63,000 \times g)$ (Chirgwin et al., 1979). The pellet was phenolchloroform-extracted, ethanol-precipitated, and resuspended in distilled $\mathrm{H}_{2} \mathrm{O}$. RNA content was quantitated by measurement of absorbance at wavelengths 260 and $280 \mathrm{~nm}$.

${ }^{32}$ P-labeled cRNA synthesis. A $1200 \mathrm{bp}$ template for preprodynorphin cRNA synthesis was obtained by SacI linearization of sp64D1.7, which contains $1700 \mathrm{bp}$ of the main exon of the rat preprodynorphin gene (Civelli et al.,1985). A 970 bp template for preproenkephalin synthesis was generated by SacI linearization of pYSEA1, kindly supplied by Dr. Steven Sabol (Yoshikawa et al., 1984). This plasmid contains virtually the entire coding region of the rat preproenkephalin cDNA from plasmid RPE2 described by Yoshikawa et al. (1984). mRNA-sense RNA was synthesized using templates oriented in the opposite direction with respect to the sp6 promoters (sp65D.17 and pYSEC-1, respectively).

Antisense mRNAs were transcribed from the linearized plasmids using sp6 polymerase, and alpha-- ${ }^{32} \mathrm{P}-$ labeled $\mathrm{rCTP}(1500 \mathrm{Ci} / \mathrm{mmol})$. mRNA sense transcripts used unlabeled rCTP. In vitro transcription was carried out as described by the manufacturer (Promega). Template was removed by DNase digestion, and RNA was precipitated with ethanol/NaAc.

Northern blotting. Aliquots of total RNA, 1-25 $\mu \mathrm{g}$, were electrophoresed through a $1.5 \%$ agarose gel containing $2.2 \mathrm{M}$ formaldehyde at $6 \mathrm{~V} / \mathrm{cm}$ using a $\mathrm{U} .04 \mathrm{~m}$ morpholinopropanesulfonic acid (MOPS, $\mathrm{pH}$ 7.0) buffer containing $10 \mathrm{~mm} \mathrm{NaAc}$ and $1 \mathrm{~mm}$ EDTA. RNA was then transferred to nylon membranes by electroblotting in $25 \mathrm{~mm}$ phosphate buffer ( $\mathrm{pH} \mathrm{6.5)}$ for $1 \mathrm{hr}$ at $25 \mathrm{~V}$ and then $2 \mathrm{hr}$ at $45 \mathrm{~V}$ at $4^{\circ} \mathrm{C}$. Blots were air-dried, baked at $80^{\circ} \mathrm{C}$ for $2 \mathrm{hr}$, prehybridized for $2 \mathrm{hr}$ at $65^{\circ} \mathrm{C}$ in $6 \times$ SSC, $5 \times$ Denhardt's solution, $100 \mu \mathrm{g} / \mathrm{ml}$ herring sperm DNA, $0.1 \% \mathrm{SDS}$, and $50 \%$ formamide, and hybridized with $1 \times 10^{7} \mathrm{dpm} / \mathrm{ml}$ of ${ }^{32}$ P-labeled probe in $6 \times \mathrm{SSC}, 1 \times$ Denhardt's, $50 \%$ deionized formamide, $100 \mu \mathrm{g} / \mathrm{ml}$ denatured herring sperm DNA, and $0.05 \%$ SDS for 


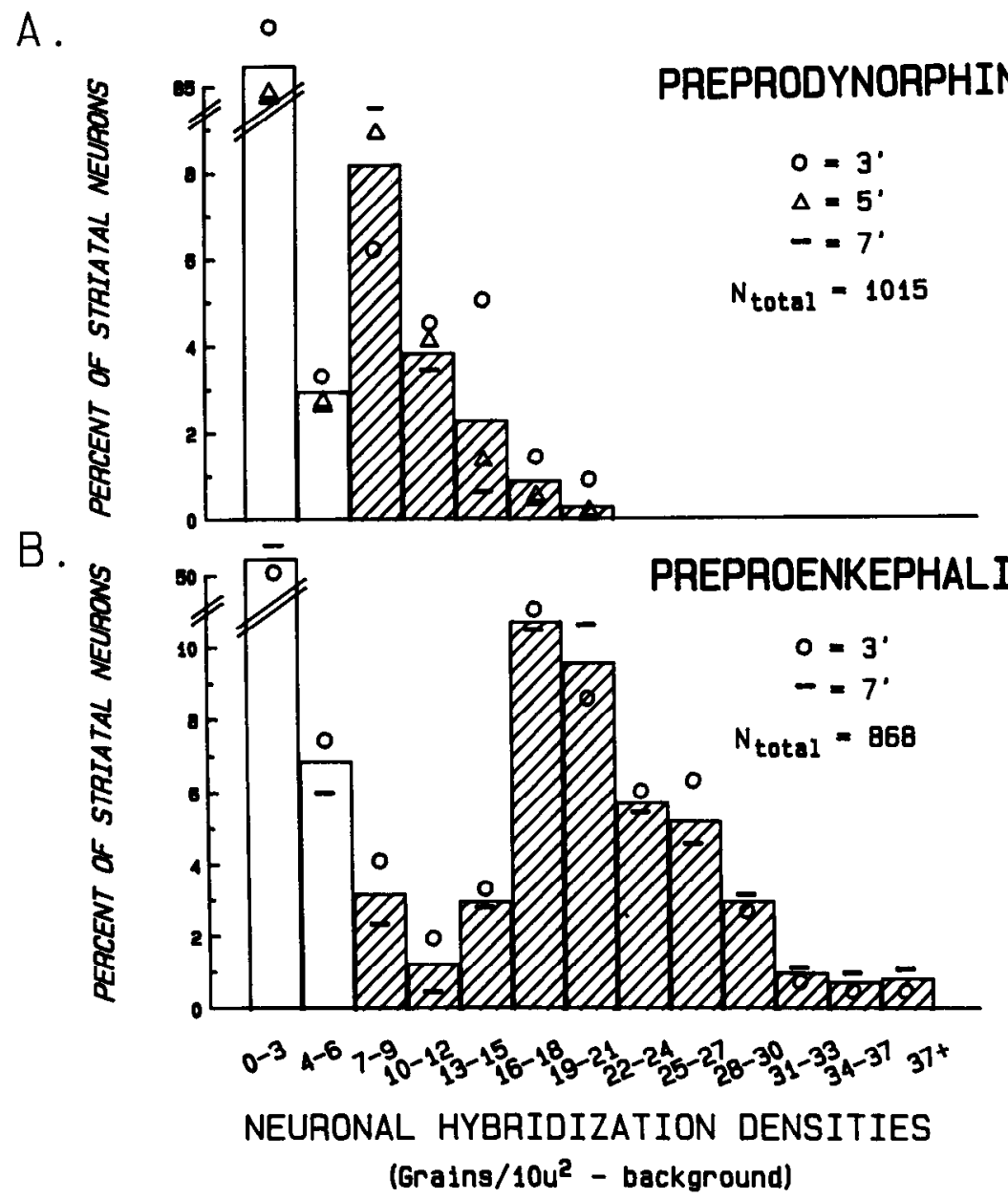

Figure 4. Frequency distribution histograms displaying the proportions of total striatal neurons exhibiting hybridization densities of differing intensities. $A$, Preprodynorphin mRNA hybridization. B, Preproenkephalin hybridization. Grain densities over individual striatal neurons were corrected for autoradiographic background and are displayed as classes in these histograms. These values are derived from experiments in which 5 serial $10 \mu \mathrm{m}$ sections through the anterior striatum were hy-. bridized with RDYN 3', RENK 3', RDYN 5', RENK 5', and DYN 7', respectively. Sequences of "syn-probe" oligonucleotides utilized were: RENK 3': 3' GGG CAC CTC GGT CTT CTT CTC CGG TTA CCT CCG CTC T 5'; RENK 7': 3' TGG AAC CGG TTG AGG AGG CTG GAC GAC TTC TCG ATG ACC 5'; RDYN 3': 3' AAC GCG TTT ATG GGG ITC TCC TGC AGG CTC TAC CGA CCC 5'; RDYN 5': $3^{\prime}$ CGT ATG TCA CAT CTT TGT ATT TTG TTC TAT ACA CGT TTT ATG 5'; RDYN 7': 3' CTT CTT CCG ATG TGC CGT GAC TGG TTC GAG AAC CTC GGG 5'. The values obtained with individual oligonucleotide cDNA probes are indicated by the symbols, while the bar heights reflect the mean values for neuronal populations hybridized with probes directed against each mRNA. Neuronal populations that were positively labeled are indicated by striped bars. These data were derived from sections taken through 5 rat brains, examined in 3 different experiments, and reflect grain counts over 1883 neurons.

$20 \mathrm{hr}$ at $65^{\circ} \mathrm{C}$. Blots were washed twice at $65^{\circ} \mathrm{C}$ with a solution of 0.1 $\times \mathrm{SSC} / 0.1 \% \mathrm{SDS}$ for $2 \mathrm{hr}$ and exposed to $\mathrm{X}$-ray film with an intensifying screen.

\section{Results}

Use of both the preproenkephalin probes and each of the 3 preprodynorphin probes results in in situ hybridization that satisfies several criteria for specificity (Uhl, 1986). The regional distribution of the hybridization with each probe parallels the regional distribution of immunoreactive neurons noted in immunohistochemical studies (e.g., Vincent et al., 1982; Williams and Dockray, 1983) and of the distribution of these mRNAs noted by other laboratories (Bloch et al., 1986; Morris et al., 1986; Siegel and Young, 1986; Shivers et al., 1986; Harlan et al., 1987; Lightman and Young, 1987). Thus, there are hybridization densities over the striatum for each probe but hybridization over the supraoptic nuclei only with the dynorphin probes (Fig. 1). Using each ${ }^{35} \mathrm{~S}$-labeled probe, hybridization is eliminated by competition with the appropriate complementary or same-sense sequence but not by competition with unlabeled cDNAs complementary to vasopressin or neuropeptide Y (Fig. $2, B, D)$. Hybridization patterns noted with ${ }^{35} \mathrm{~S}$-labeled preproenkephalin or preprodynorphin cDNAs are different from those obtained with similarly prepared cDNAs directed against vasopressin or somatostatin (data not shown). RNAse treatment of sections also results in loss of specific hybridization (Fig. $2 E$ ). In experiments with varying wash temperatures, specific hy- bridization remains at temperatures of $65^{\circ} \mathrm{C}$, although several sections were washed from slides under these conditions (data not shown).

In microscopic examination of emulsion autoradiograms, hybridization densities were noted over many individual neurons that were 3 or more times greater than background values; we consider these neurons to be positively labcled (Fig. 3). Qualitative studies of these positively expressing cells reveal several interesting features. First, the characteristics of the cells positively labeled by the 2 preproenkephalin probes are similar to each other, as were those of cells labeled by each of the 3 preprodynorphin probes. These 2 mRNAs appear not be expressed in many of the same striatal neurons, however. In preliminary studies of adjacent $5 \mu \mathrm{m}$ serial sections hybridized with probes directed against preproenkephalin and preprodynorphin mRNAs, neurons that hybridized with probes against one mRNA were identified in cell-stained profile in the adjacent section. Forty neurons situated next to clear-cut landmarks such as blood vessels were identified and examined in both serial sections. Only one of the neurons examined appeared to display positive hybridization with both probes; each of the other dynorphin mRNA-positive neurons was enkephalin mRNA-negative, and vice versa (data not shown). Both enkephalin- and dynorphinmRNAs are more concentrated in ventral aspects of the striatum (Figs. 1 and 2). Each of these mRNAs is found in mediumsized, but not in larger $(>30 \mu \mathrm{m})$ diameter striatal neurons examined (Fig. 3) (e.g., Vincent et al., 1982; Harlan et al., 1987). 
Figure 5. Northern analysis of preproenkephalin (lower band) and preprodynorphin (upper band) mRNA in $25,12,4$, and $1 \mu \mathrm{g}$ samples of total RNA extracted from normal rat striata. RNA was prepared, quantitated spectrophotometrically, subjected to denaturing agarose gel electrophoresis and electroblotting, and probed with equal amounts of ${ }^{32} \mathrm{P}$-labeled cRNAs directed against preproenkephalin and preprodynorphin mRNAs with hybridization, washing, and autoradiographic conditions as described in the text. Blots were standardized with mRNA-sense sp6 products as described. Serial hybridization also confirmed the identity of each band. The lower marker indicates the position of a 970 base mRNA-sense preproenkephalin-like sp6 RNA product detected by hybridization with the ${ }^{32} \mathrm{P}$-labeled preproenkephalin cRNA; the upper marker indicates the position of a $1.7 \mathrm{~kb}$ mRNA-sense preprodynorphin-like sp6 RNA product detected by hybridization with the ${ }^{32} \mathrm{P}$-labeled preprodynorphin cRNA. Hybridization densities to the preproenkephalin mRNA in $4 \mu \mathrm{g}$ total RNA are almost as high as those for dynorphin mRNA in 12-25 $\mu \mathrm{g}$ RNA.

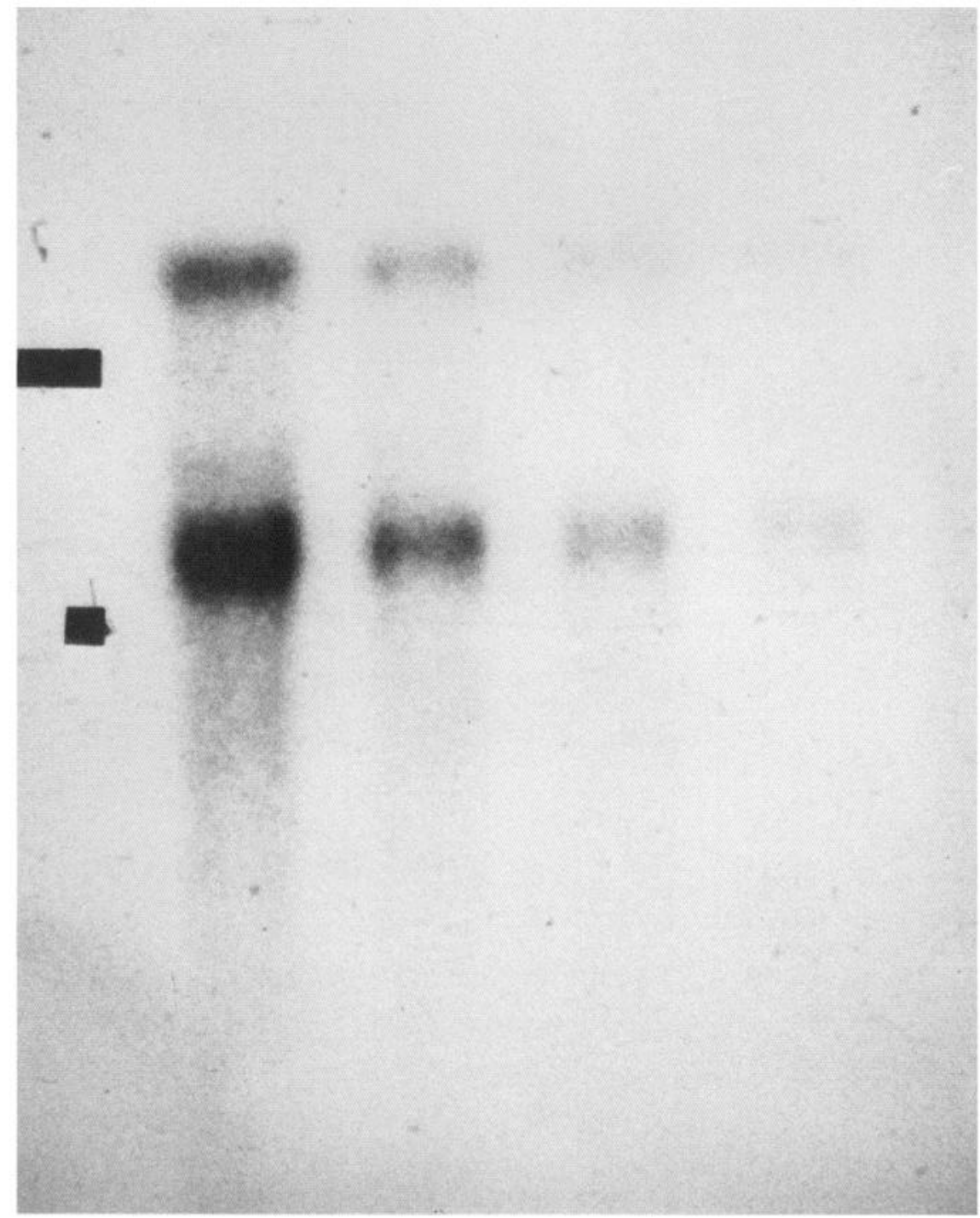

Clustering of enkephalin-positive neurons is frequently evident (Fig. 3). Although dynorphin mRNA-expressing neurons were occasionally seen near each other, relatively isolated positively hybridizing cells are most common.

The validity of our approach to relative quantitative analyses of cellular hybridization densities was supported by several results. ${ }^{35}$ S-labeled autoradiographic standards revealed a linear relationship between radioactivity and grain density under these conditions. Observation of hybridization densities overlying mRNA-sense standards constructed by immobilizing known amounts of mRNA-sense sp6 product to nylon filter squares revealed a linear relationship between hybridization intensity and amounts of RNA over this several-fold range (data not shown). The observed differences in hybridization density were maintained for several different probes directed at each mRNA and occurred in experiments in which probe concentrations varied over a 5-fold range.

Quantitative analysis of the grain densities overlying neurons after hybridization with each of the preproenkephalin probes revealed grain densities that were substantially above background values in many neurons, with over $40-50 \%$ of all striatal neurons displaying relatively clear positive hybridization (Fig.
$4 B)$. Conversely, hybridization with dynorphin probes under conditions in which we could compare the hybridization signal to that for the preproenkephalin probes demonstrated hybridization densities that were above, but closer to, background values in a smaller fraction of neurons. If we divided the labeled from the unlabeled neurons in the fashion shown in Figure 4A, fewer than $20 \%$ of striatal neurons were positive for hybridization with any of the 3 different cDNAs directed against different regions of the preprodynorphin mRNA. However, it remains possible that the lower signal-to-noise ratio for neurons expressing preprodynorphin mRNA could have allowed us to include a subpopulation of neurons expressing at low levels among the "nonexpressing" category.

The intensities of preproenkephalin and preprodynorphin hybridization to positively expressing neurons were also different from each other (Fig. 4). Hybridization to enkephalin-positive neurons was more than twice the density of hybridization to dynorphin-positive neurons. These results also held true using several probes directed against differing portions of each mRNA.

Northern analysis of RNA extracted from the striatum confirms the preponderance of preproenkephalin, using cRNA hybridization probes that are similar to each other but entirely 


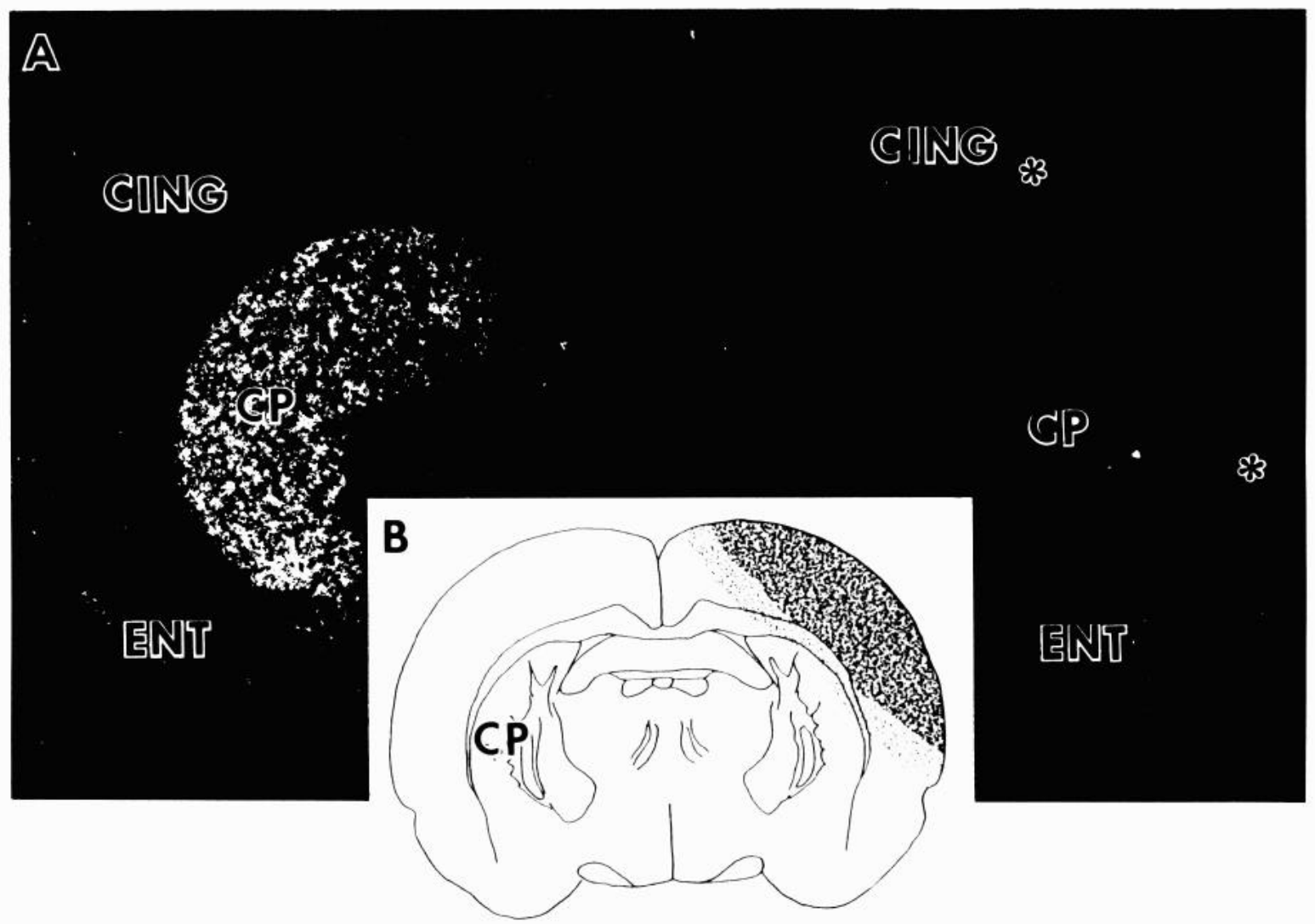

Figure 6. A, Hybridization densities for a preproenkephalin cDNA (RENK $3^{\prime}$ ) in a section through the midstriatum of a rat subjected to a rightsided cerebral cortical aspiration lesion $5 \mathrm{~d}$ before sacrifice. Asterisks mark the borders of the cerebral cortical lesion; cing, cingulate cortex; ent, entorhinal cortex, $c p$, striatum. Original magnification, $\times 14$. Tissue of the right striatum was intact, despite loss of hybridization signal. $B$, Diagram showing the minimal (dark stipple) and maximal (light stipple) extents of cerebral cortical lesions in animals used for these studies. Lesions covered $60-75 \%$ of the distance between frontal and occipital poles.

different from the cDNA probes used for in situ studies. Hybridization to enkephalin mRNA in $4 \mu \mathrm{g}$ of the RNA was almost as intense as hybridization to the dynorphin mRNA contained in 12-25 $\mu \mathrm{g}$ of this RNA (Fig. 5). This held true in 4 replications of this experiment.

In situ examination of brains taken from animals with unilateral cerebral cortical aspiration lesions revealed asymmetric hybridization densities for preproenkephalin mRNA (Fig. 6). Examination of the cellular basis for this change demonstrated that ca. $50 \%$ of neurons exhibited hybridization densities above background in the striata contralateral and ipsilateral to the lesion (Figs. 7, 8). However, the lesioned side showed a reduction in the intensity of hybridization over the positively labeled cell population. This change developed largely between 1 and $5 \mathrm{~d}$ following the lesion. Interestingly, however, no asymmetry was found in the intensity of enkephalin-mRNA hybridization over neurons in a closely adjacent structure, the central nucleus of the amygdala. Hybridization densities over positive neuron samples from the control and lesioned sides of the central amygdala were virtually identical $11 \mathrm{~d}$ after cortical lesions (data not shown).

Hybridization of a ${ }^{32} \mathrm{P}$-labeled cDNA directed against tubulin mRNA was also examined in film autoradiograms of sections taken from these same brains. These autoradiograms showed no differences in hybridization densities between the midstriatum ipsilateral and contralateral to the cerebral cortical lesions (data not shown).

\section{Discussion}

The major findings of this study are that preproenkephalin is the most prominently expressed striatal opioid peptide gene at both regional and cellular levels and that cerebral cortical inputs are required to maintain these high levels of cellular preproenkephalin mRNA expression. These results also underscore the utility and the limitations of this approach to determining the relative levels of expression of 2 genes, at a cellular level.

Several features of the observed in situ hybridization suggest that preproenkephalin and preprodynorphin mRNAs are being identified in these studies. The striatal in situ hybridization densities noted for preproenkephalin mRNA parallel the density of mRNA and peptide noted in work from other laboratories (e.g, Penny et al., 1986; Shivers et al., 1986). Two different probes directed against different regions of the preproenkephalin mRNA recognize it in identical patterns, while 3 similar-sized cDNA probes directed against preprodynorphin mRNA display patterns that are similar to each other but different from patterns observed with the preproenkephalin probes. Competition experiments further demonstrate specificity; competition with excess cDNA corresponding to the probes utilized virtually eliminates hybridization. RNAse pretreatment of sections substantially reduces hybridization densities. The hybridization survives washes of elevated temperature, suggesting that the targeted sequences are closely complementary to the probe sequences utilized. 
A.

B.

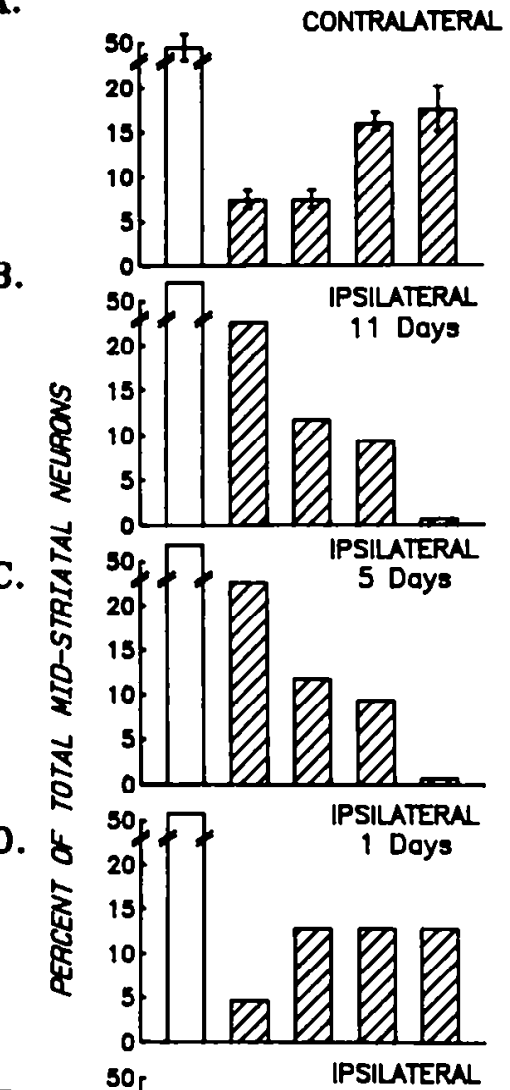

E.

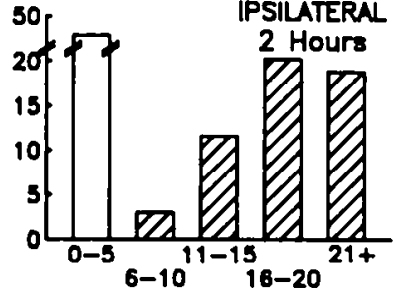

\section{NEURONAL HYBRIDIZATION DENSITIES \\ (Groins/10u 2 -background)}

Figure 7. Cellular bases and time course of the influences of unilateral cerebral cortical aspiration lesions on preproenkephalin mRNA hybridization densities in neurons lying in the midstriatum contralateral $(A)$ or ipsilateral $(B-E)$ to the lesion. Hybridization densities of RENK $3^{\prime}$ to 1048 individual striatal neurons in sections from 12 brains were estimated, corrected for autoradiographic background, and grouped according to hybridization densities as noted above. Values in the "control" striata were similar at each time point following lesions. $A$, Mean \pm SEM of control values from the 4 groups sacrificed at different time points after the lesion. $B-E$, Midstriatal values from the lesioned side obtained in sections from groups of 3 animals sacrificed at $11 \mathrm{~d}(B), 5$ $\mathrm{d}(C), 24 \mathrm{hr}(D)$, or $2 \mathrm{hr}(E)$ following cortical lesions. Unlabeled neurons $\left(0-5\right.$ grains $\left./ 10 \mu \mathrm{m}^{2}\right)$ were $49.5 \%$ for the control side and ranged from $45-59 \%$ on the lesioned side.

Several aspects of the data also provide support for the validity of our approach for determining the fraction of striatal neurons expressing each mRNA and the relative level of expression in each positive cell. The similarity between results obtained with different probes recognizing different portions of each mRNA argues for such validity. Second, the agreement between our results and recent immunohistochemical and in situ hybridization studies of preproenkephalin gene expression are encouraging. Forty to fifty percent of striatal neurons are reported to be enkephalin immunopositive, and slightly more
FRACTION OF NEURONS POSITIVELY HYBRIDIZING
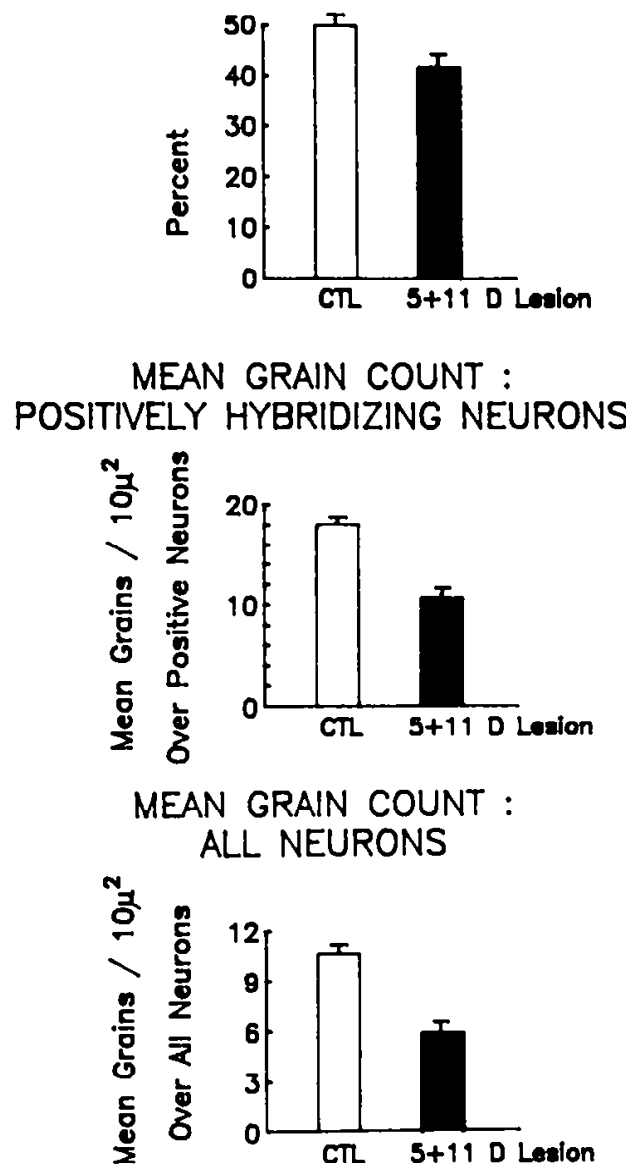

Figure 8. Distribution of midstriatal neuronal preproenkephalin mRNA hybridization densities ipsilateral (solid bar) and contralateral (open bar) to unilateral cerebral cortical aspiration lesions. Data from animals sacrificed 5 and $11 \mathrm{~d}$ after the lesions are pooled here. Top. Fraction of neurons that display positive hybridization. Middle, Mean grain density over positively hybridizing neurons. Bottom, Mean grain density over all ncurons. Bars. SEM. The differences displayed in both the middle and bottom panels achieve statistical significance $(p<0.01)$.

than half these cells hybridized to a complementary RNA probe directed against preproenkephalin mRNA (Penny et al., 1986; Shivers et al., 1986). Third, the convergence of our in situ hybridization results with those obtained from Northern analyses of extracted mRNA gives credence to each of these methods for relative quantitation. These ca. 4-fold differences between the concentrations of striatal preproenkephalin and preprodynorphin mRNAs are also found in solution hybridization studies in bovine and porcine tissues (Pittius et al., 1985, 1987).

In interpreting our results, however, we also need to keep in mind the limitations imposed by our approach. The dynamic nature of these neuronal patterns of expression may allow both the fraction of expressing neurons and the intensity of expression in positive cells to vary among populations of animals sacrificed after different intensities of, for example, locomotor activity. In the nucleus caudalis, changes in the activities of primary afferent inputs can alter each of these aspects of neuronal gene expression (Nishimori et al., 1988). The results obtained in our studies thus might not be comparable to those achieved in studies of animals maintained under different conditions. Several concerns of tech- 
nique are also important. At the probe concentrations and autoradiographic exposures used, grain densities over the most positive enkephalin-expressing neurons approached levels providing emulsion saturation when hybridization values over most of the preproenkephalin-expressing neurons were many times background values. On the other hand, when we used these same constraints on the autoradiographic exposures for the 3 preprodynorphin probes, the hybridization values overlying the neurons identified as preprodynorphin-expressing were closer to background values. While we are thus confident about the specificity of our procedures, suboptimal sensitivity for detection of neurons expressing preprodynorphin mRNA at low levels could have 2 consequences. First, we could conceivably be including neurons that express their preprodynorphin genes at lower levels among the cells thought to be nonexpressing. Preliminary immunohistochemical results suggest that a larger population of striatal neurons immunoreact with antisera with some specificity for dynorphin (S. Kitai, personal communication). However, on examination of emulsion autoradiograms hybridized with preprodynorphin cDNA probes and allowed to expose for longer periods of time, we are unable to find a substantial increase in the fraction of dynorphin mRNA-expressing neurons. Second, we are less confident about our abilities to detect the cellular basis of the further declines in levels of expression of this gene that we have noted in preliminary studies of lesioned animals. We have thus used this material to define lesion-induced changes only in the more robustly expressed preproenkephalin gene.

It is conceivable that selective accessibility of our probes to dynorphin and enkephalin mRNAs could contribute to the differences noted with in situ studies (Uhl, 1988). Such selective access could be imposed if the neurons using one transmitter were more permeable to probes than those using the other neuropeptide. It could also conceivably result if differences in translational activity led to greater steric blockade of one mRNA by ribosomes than the other. Since both of the mRNAs are expressed in neurons of similar size and since studies with extracted RNA yield parallel results, we feel that it is unlikely that differential access to probes plays a major role in our observed results.

A priori we could imagine that differences between striatal preproenkephalin and preprodynorphin mRNA hybridization densities could be duc to differences in the densities of expressing cells or to differences in the intensity of expression in each positive cell. Our results suggest that both of these factors appear to combine to make preproenkephalin the dominantly expressed opioid peptide in the striatum. Evidence from an increasing number of systems suggests that cellular levels of peptide-specific mRNA may reflect the functional activities of particular peptidergic cells (Habener, 1981). If this is true in these striatal neurons, our findings would point toward substantially greater activity in striatal enkephalin neurons than in those utilizing dynorphin.

Enkephalin-expressing striatal neurons demonstrate decreasing levels of preproenkephalin mRNA following cortical lesions. The preservation of preproenkephalin $\mathrm{mRNA}$ levels in neurons of the adjacent central nucleus of the amygdala, the maintenance of striatal neuronal morphologies, and the persistence of tubulin mRNA levels in the striatum all argue for the specificity of these effects. These results are consistent with a loss of synaptically mediated cerebral cortical input that could normally excite the striatal neurons (Penney and Young, 1983). Conceivably, a cortical "trophic factor" could also be involved. Several labora- tories have demonstrated that blocking another striatal input, the presumably inhibitory influence of dopamine, results in increased levels of preproenkephalin mRNA in expressing cells (Tang et al., 1983; Brann et al., 1986). Both excitatory and inhibitory manipulations of striatal inputs thus act to alter the levels of expression of preproenkephalin within the same fraction of positive cells, rather than to change markedly the number of total striatal neurons that express this peptide mRNA. This alteration thus appears to provide another example of dynamic plasticity in ncuronal ncuropeptide gene expression that can be correlated with alterations in neuronal functional activity (Uhl et al., 1986).

\section{References}

Akil, H., S. J. Watson, E. Young, M. E. Lewis, H. Khachaturian, and J. M. Walker (1984) Endogenous opioids: Biology and function. Annu. Rev. Neurosci. 7: 223-255.

Bloch, B., T. Popobich, S. Chouham, and C. Kowalski (1986) Detection of the mRNA coding for enkephalin precursor in the rat brain and adrenal by using an in situ hybridization procedure. Neurosci. Lett. 64: 29-34.

Brahic, M., and A. T. Haase (1978) Detection of viral sequences of low reiteration frequency by in situ hybridization. Proc. Natl. Acad. Sci. USA 75: 6125-6129.

Brann, M. R., T. I. Bonner, and W. S. Young (1986) Mesencephalic dopamine neurons control the expression of neuropeptide mRNAs in the rat forebrain. Soc. Neurosci. Abstr. 12:761.

Chavkin, C., I. F. James, and A. Goldstein (1982) Dynorphin is a specific endogenous ligand of the kappa opioid receptor. Science 215: 413-415.

Chirgwin, J. M., A. E. Przybyla, R. J. MacDonald, and W. J. Rutter (1979) Isolation of biologically active RNA from sources enriched in ribonuclease. Biochemistry 18: 5294-5299.

Christensson-Nylander, I., M. Herrera-Marschitz, W. Staines, T. Hökfelt, T. L. Terenium, U. Ungerstedt, C. Cuello, W. H. Oertel, and M. Goldstein (1986) Striatonigral dynorphin and substance $P$ pathways in the rat. Exp. Brain Res. 64: 169-192.

Civelli, O., J. Douglass, A. Goldstein, and E. Herbert (1985) Structure and expression of the rat preprodynorphin gene. Proc. Natl. Acad. Sci. USA 82: 4291-4295.

Comb, M., P. H. Sccburg, J. Adelman, L. Eiden, and E. Herbert (1982) Primary structure of the human met- and leu-enkephalin precursor and its mRNA. Nature 295: 663-666.

DiFiglia, M., N. Aronin, and J. B. Martin (1982) Light and electron microscopic localization of immunoreactive leu-enkephalin in the monkey basal ganglia. J. Neurosci. 2: 303-320.

Elde, R., T. Hökfelt, O. Johansson, and L. Terenius (1976) Immunohistochemical studies using antibodies to leucine-enkephalin: Initial observations on the nervous system of the rat. Neuroscience 1 : 349-351.

Gee, C. E., C. C. Chen, and J. L. Roberts (1983) Identification of proopiomelanocortin neurons in rat hypothalamus by in situ cDNAmRNA hybridization. Nature 306: 374-376.

Goodman, R. R., and S. H. Snyder (1982) $\kappa$ opiate receptors localized by autoradiography to deep layers of cerebral cortex: Relation to sedative effects. Proc. Natl. Acad. Sci. USA 79: 5703-5707.

Goodman, R. R., S. H. Snyder, M. J. Kuhar, and W. S. Young (1980) Differentiation of delta and mu opiate receptor localizations by light microscopic autoradiography. Proc. Natl. Acad. Sci. USA 77: 62396243.

Graybiel, A. M., C. W. Ragsdale, Jr., E. S. Yoneoka, and R. P. Elde (1981) An immunohistochemical study of enkephalins and other neuropeptides in the striatum of the cat with evidence that the opiate peptides are arranged to form mosaic patterns in register with the striosomal compartments visible by acetylcholinesterase staining. Neuroscience 6: 377-397.

Habener, J. F. (1981) Principles of peptide hormone biosynthesis. In Neurosecretion and Brain Peptides, J. Martin, S. Reichlin, and K. Blick, cds., pp. 21-34, Raven, New York.

Harlan, R. E., B. D. Shivers, G. J. Romano, R. D. Howells, and D. W. Pfaff (1987) Localization of preproenkephalin mRNA in the rat 
brain and spinal cord by in situ hybridization. J. Comp. Neurol. 258: 159-184.

Hökfelt, T., R. Elde, O. Johansson, L. Terenius, and L. Stein (1977) The distribution of enkephalin-immunoreactive cell bodies in the rat central nervous system. Neurosci. Lett. 5: 25-31.

Horikawa, S., T. Takai, M. Toyosato, H. Takahashi, M. Noda, H. Kakidani, T. Kubo, T. Hirose, S. Inayama, H. Hayashida, T. Miyata, and S. Numa (1983) Relation and structural organization of the human preproenkephalin B gene. Nature 306: 611-614.

Howells, R. D., D. L. Kilpatrick, R. Bhatt, J. J. Monahan, M. Poonian, and S. Udenfriend (1984) Molecular cloning and sequence determination of rat preproenkephalin cDNA: Sensitive probe for studying transcriptional changes in rat tissues. Proc. Natl. Acad. Sci. USA 81: $7651-7655$.

Lightman, S. L., and W. S. Young (1987) Changes in hypothalamic preproenkephalin A mRNA following stress and opiate withdrawal. Nature 328: 643-645.

Lord, J. A. H., A. A. Waterfield, J. Hughes, and H. W. Kosterlitz (1977) Endogenous opioid peptides: Multiple agonists and receptors. Nature 267: 495-499.

Morris, B. J., I. Haarmann, B. Kempter, V. Hollt, and A. Herz (1986) Localization of prodynorphin mRNA in rat brain by in situ hybridization using a synthetic oligonucleotide probe. Neurosci. Lett. 69: 104-108.

Nishimori, T., M. Moskowitz, and G. Uhl (1988) Opioid peptide gene expression in rat nucleus caudalis neurons: Normal distribution and effects of trigeminal deafferentiation. J. Comp. Neurol. 274: 142-151.

Noda, M., Y. Teranishi, H. Takahashi, M. Toyosato, M. Notake, S. Nakanishi, and S. Numa (1982a) Isolation and structural organization of the human preproenkephalin gene. Nature 297: 431-434.

Noda, M., Y. Furitani, H. Takahashi, M. Toyosato, T. Hirose, S. Imayama, S. Nakanishi, and S. Numa (1982b) Cloning and sequence analysis of cDNA for bovine adrenal preproenkephalin. Nature 295: 202-296.

Penney, J. B., and A. B. Young (1983) Speculations on the function of basal ganglion disorders. Annu. Rev. Neurosci. 6: 73-94.

Penny, G. R., S. Afsharpour, and S. T. Kitai (1986) The GAD, Leuenkephalin, Met-enkephalin, and substance P-immunoreactive neurons in the neostriatum of the rat and cat: Evidence for partial population overlap. Neuroscience 17: 1011-1045.

Pittius, C. W., N. Kley, J. P. Loeffler, and V. Hollt (1985) Quantitation of preproenkephalin A mRNA in bovine brain, pituitary, and adrenal medulla. EMBO J. 4: 1257-1260.

Pittius, C. W., N. Kley, J. P. Loeffler, and V. Hollt (1987) Preproenkephalin B mRNA in porcine tissues. J. Neurochem. 48: 586-592.

Robson, L. E., S. J. Paterson, and H. W. Kosterlitz (1983) Opiate receptors. Handb. Psychopharmacol. 17: 13.

Rosen, H., J. Douglass, and E. Herbert (1984) Isolation and characterization of the rat preproenkephalin gene. J. Biol. Chem. 259: 1430914313.

Shivers, B. D., R. E. Harlan, G. J. Romano, R. D. Howells, and D. W.
Pfaff (1986) Cellular localization of preenkephalin mRNA in rat brain: Gene expression in the caudate-putamen and cerebellar cortex. Proc. Natl. Acad. Sci. USA 83: 6221-6225.

Siegel, R. E., and W. S. Young (1986) Detection of preprocholecystokinin and preproenkephalin A mRNAs in rat brain by hybridization histochemistry using complementary RNA probes. Neuropeptides 6 : 573-580.

Snyder, S. H., and S. R. Childers (1979) Opiate receptors and opioid peptides. Annu. Rev. Neurosci. 2: 35-64.

Tang, F., E. Costa, and J. P. Schwartz (1983) Increase of proenkephalin mRNA and enkephalin in content of rat striatum after daily injection of haloperidol for 2 to 3 weeks. Proc. Natl. Acad. Sci. USA 80: 38413844.

Uhl, G. R. (1986) Determination of specificity in in situ hybridization. In In Situ Hybridization in Brain, G. R. Uhl, ed., pp. 253-256, Plenum, New York.

Uhl, G. R. (1988) In situ hybridization: Issues with quantitation using radiolabeled hybridization probes. In Methods in Enzymology, M. Conn, ed., Academic, New York.

Uhl, G. R., and S. M. Reppert (1987) Suprachiasmatic nucleus vasopressin mRNA: Circadian variation in normal and Brattleboro rats. Science 232: 390-393.

Uhl, G. R., and C. A. Sasek (1986) Somatostatin mRNA: Regional variation in hybridization densities in individual neurons. J. Neurosci. 6: 3258-3264.

Uhl, G. R., M. J. Kuhar, and S. H. Snyder (1978a) Enkephalin and neurotensin: Immunohistochemical localization and identification of an amygdalafugal pathway. In Endorphins: Advances in Biochemical Psychopharmacology, Vol. 18, E. Costa and M. Trabucci, eds., pp. 71-87, Raven, New York.

Uhl, G. R., M. J. Kuhar, and S. H. Snyder (1978b) Enkephalin-containing pathway: Amygdaloid efferents in stria terminalis. Brain Res. 149: 223-228.

Uhl, G. R., H. Zingg, and J. F. Habener (1985) Vasopressin mRNA in situ hybridization: Localization and regulation studies with oligonucleotide cDNA probes in normal and Brattleboro rat hypothalamus. Proc. Natl. Acad. Sci. USA 82: 5555-5559.

Uhl, G. R., J. Evans, M. Parta, C. Walsworth, K. Hill, C. Sasek, M. Voigt, and S. R. Reppert (1986) Vasopression and somatostatin mRNA in situ hybridization. In In Situ Hybridization in Brain, G. R. Uhl, ed., pp. 21-48, Plenum, New York.

Vincent, S. R., T. Hökfelt, I. Christensson, and L. Terenius (1982) Dynorphin-immunoreactivity in rat brain. Neurosci. Lett. 33: 185190.

Williams, R. G., and G. J. Dockray (1983) Distribution of enkephalinrelated peptides in rat brain: Immunohistochemical studies using antisera to met-enkephalin and met-enkephalin $\mathrm{Arg}^{6} \mathrm{Phe}^{7}$. Neuroscience 9: 563-586.

Yoshikawa, K., C. Williams, and S. L. Sabol (1984) Rat brain preproenkephalin mRNA. J. Biol. Chem. 259: 14308. 